\title{
AN ECOLOGICAL APPROACH TO BRYOPHYTES OF BEEHIVE YARDS: IS THERE A BEE-MOSS RELATIONSHIP?
}

\author{
GRDOVIĆ SVETLANA* and SABOVLJEVIĆ M** \\ ${ }^{*}$ Faculty of Veterinary Medicine, Belgrade \\ ${ }^{* *}$ Faculty of Biology, Belgrade
}

(Received 12. April 2007)

The bryophyte flora composition of three beehive yards in a wide area of Belgrade has been studied. The bryophyte vegetation abundance in the studied areas, as well as its diversity have been compared. The aim of this study was to find out the relationship between bees and mosses, if any. Observations of bees visiting bryophytes were made. According to our observations, bees visit bryophytes only facultatively. However, the indirect relationships statistically supported (PCA, CCA) the influence of bryophytes to bees, and vice versa. The indirect relationship of bryophyte and bees was found and statistically supported. Bryophytes influence humidity and maintain a milder microclimate for flowering plants growing above them and so give them longer turgescency during the dry periods, making them more flurishing. This is of an indirect influence to bees which then do not have to visit distant pastures.

Key words: bryophytes, flora, bees, beehive yards

\section{INTRODUCTION}

Bryophytes are an old group of higher non vascular plants, originated from the Devonian era, according to paleobotanical findings. Recent estimations show that there are 15000 recent bryophyte species worldwide (Frahm, 2001) and still new recent and fossil species are described.

Bryophytes comprise a significant part of meadow plants species, however not huge in size they remain overlooked. On the other hand the relationships of bryophytes with insects are unknown and not so obvious (Frahm, 2001).

It has been shown that many invertebrate groups including insects have diverse and complex relationships with bryophytes (Gerson, 1982). It is not considered that bees have any relationships with mosses, however some other species from the group Hymenoptera facultatively or obligatorily stick to moss patches. Thus, Myrmica ruginosis and Formica picea nest among peat mosses (Matthey, 1971), and act as major predators when bogs dry up. Some insects overwinter in moss patches, some lay eggs or spend the larvae phase (ovposition and pupation) in mosses (Gerson, 1982; Ando and Matsuo, 1984). Harvesting 
ants Messor spp. climb the setae and cut off the capsules which probably serve as substitute food until phanerogam seeds become available, later in the season (Gerson, 1982). Some insects show such a relationships with some mosses that their distribution patterns overlap (Schofield, 1985).

The studies on bryophytes related to bees are few. All the above mentioned are reports of case observations and the results given here are the first of this type.

Sabovljević and Sabovljević (2007) reported that extracts of some liverworts can be used either as antifeedants for some plant leaf feeding insects, or also to affect the growth and development of plants. In Chinese traditional medicine, honey is mixed with some bryophyte species growing in beehive yards to cure some health problems (Sabovljević et al., 2001).

According to Grdović $(1997,2003)$ the urban area of Belgrade is divided into four zones according to air quality, related to bryophyte species composition which is used as a bioindicator of aerosediments such as Sulphur (IV) oxide and lampblack.

\section{MATERIAL AND METHODS}

Three different beehive yards in Belgrade wide area have been chosen to test the relationships of bryophyte composition on beehive yards, and its relationships (if any) to bees. A classical methodology in sampling bryophytes was used. Statistical aproach (PCA, CCA) was used to asses the relations found (Jolliffe, 1986; Wagner, 2004). The parameters observed were the number of bryophyte species, number of bees which visited bryophytes and the level of turgescency. Green cover and flowering intensity were taken in percentages and transferred to numerical matrices for statistical counting. The Hallingbäck (1996) indices were used to asses bryological preferences within beehive yards.

The first beehive yard (FVM- Faculty of Veterinary Medicine) is situated not far from Belgrade center, the second and third are chosen to be outside the urban area, but in ecologically different situations. The bryophyte composition and cover in the yards has been studied, as well as the potential relationships to the bees.

\section{RESULTS AND DISCUSSION}

The studied beehive yards count 4 hepatic and 70 moss species (Table 1). Interestingly common species for all three sites are only three (Amblystegium serpens (Hedw.) Schimp., Hypnum cupressiforme Hedw. and Tortula muralis Hedw.). Bryophytes common for the beehive yards of the Faculty of Veterinary Medicine and Rušanj woods are: Barbula convoluta Hedw., Bryum argenteum Hedw., Ceratodon purpureus (Hedw.) Brid. and Leskea polycarpa Hedw. The beehive yards of the Faculty of Veterinary Medicine and Višnjica have in common three moss species, Bryum capillare Hedw., Grimmia pulvinata (Hedw.) Sm. and Leptodyctium riparium (Hedw.) Warnst. The beehive yards in Rušanj woods and Višnjica have in common the following species: Brachythecium rutabulum (Hedw.) Schimp., Ditrichum flexicaule (Schwagr.) Hampe, Ditrichum pallidum (Hedw.) 
of beehive yards: is there a bee-moss relationship?

Hampe and Homalothecium sericeum (Hedw.) Schimp. Additional 60 bryophyte species were exclusive for the one of the beehive yards studied (Table 1).

Table 1. The bryophyte species exclusive for the one of the beehive yards 1. FVM Faculty of Veterinary Medicine, 2. Rušanj woods and 3. Višnjica

\begin{tabular}{|c|c|c|c|c|}
\hline & Species & 1 & 2 & 3 \\
\hline 1. & Chiloscyphus polyanthos (L.) Corda & & + & \\
\hline 2. & Conocephalum conicum (L.) Dumort. & & + & \\
\hline 3. & Marchantia polymorpha L. & & + & \\
\hline 4. & Radula complanata (L.) Dumort. & & + & \\
\hline 5. & Amblystegium subtile (Hedw.) Schimp. & & + & \\
\hline 6. & Hygroamblystegium tenax (Hedw.) Jenn. & & + & \\
\hline 7. & Anomodon viticulosus (Hedw.) Hook.\&Taylor & & + & \\
\hline 8. & Atrichum undulatum (Hedw.) P.Beauv. & & + & \\
\hline 9. & Barbula unguiculata Hedw. & & + & \\
\hline 10. & Brachythecium campestre (Mull.Hal.) Schimp. & & + & \\
\hline 11. & Brachythecium glareosum (Bruch ex Spruce) Schimp. & & + & \\
\hline 12. & Brachythecium rivulare Schimp. & & + & \\
\hline 13. & Brachythecium salebrosum (Hoffm. ex F. Weber \& D. Mohr) Schimp. & & + & \\
\hline 14. & Brachytheciastrum velutinum (Hedw.) Ignatov \& Huttunen & & + & \\
\hline 15. & Bryum dichotomum Hedw. & + & & \\
\hline 16. & Bryum moravicum Podp. & & + & \\
\hline 17. & Bryum pallens Sw. & & & + \\
\hline 18. & Bryum pallescens Schleich. \&Schwagr. & & & + \\
\hline 19. & Bryum pseudotriquetrum (Hedw.) P. Gaertn. et al. & & + & \\
\hline 20. & Bryum weigelli Spreng. & & + & \\
\hline 21. & Calliergonella cuspidata (Hedw.) Loeske & & + & \\
\hline 22. & Cratoneuron filicinum (Hedw.) Spruce & & + & \\
\hline 23. & Cirriphyllum piliferum (Hedw.) Grout & & + & \\
\hline 24. & Dichodontium pellucidum (Hedw.) Schimp. & & + & \\
\hline 25. & Dicranum scoparium Hedw. & & & + \\
\hline 26. & Didymodon insulanus (De Not.) M. O. Hill & & & + \\
\hline 27. & Didymodon rigidulus Hedw. & + & & \\
\hline 28. & Didymodon spadiceus (Mitt.) Limpr. & & + & \\
\hline 29. & Ditrichum heteromallum (Hedw.) E. Britton & & & + \\
\hline 30. & Encalypta vulgaris Hedw. & & & + \\
\hline 31. & Entodon concinnus (De Not.) Paris & & + & \\
\hline 32. & Kindbergia praelonga (Hedw.) Ochyra & & + & \\
\hline 33. & Plasteurhynchium meridionale (Schimp.) M. Fleisch. & + & & \\
\hline 34. & Eurhynchiastrum pulchellum (Hedw.) Ignatov \& Huttunen & + & & \\
\hline 35. & Oxyrrhynchium hians (Hedw.) Loeske & + & & \\
\hline
\end{tabular}




\begin{tabular}{|c|c|c|c|c|}
\hline \\
\hline \multicolumn{5}{|c|}{\begin{tabular}{l|l} 
Cont. Table 1 \\
36. & Oxyrrhynchium
\end{tabular}} \\
\hline 37. & Eurhynchium striatum (Hedw.) Schimp. & & + & \\
\hline 38. & Fissidens dubius P.Beauv. & & + & \\
\hline 39. & Funaria hygrometrica Hedw. & + & & \\
\hline 40. & Grimmia laevigata (Brid.) Brid. & & + & \\
\hline 41. & Grimmia trichophylla Grev. & & & + \\
\hline 42. & Gymnostomum aeruginosum Sm. & & + & \\
\hline 43. & Homalothecium lutescens (Hedw.) H. Rob. & & + & \\
\hline 44. & Homomallium incurvatum (Schrad. ex Brid.) Loeske & & + & \\
\hline 45. & Hypnum lacunosum (Brid.) G. F. Hoffman ex Brid. & & + & \\
\hline 46. & Hypnum resupinatum Taylor & & + & \\
\hline 47. & Isothecium myosuroides Brid. & & + & \\
\hline 48. & Orthotrichum affine Schrad. ex Brid. & & + & \\
\hline 49. & Orthotrichum anomalum Hedw. & & + & \\
\hline 50. & Orthotrichum diaphanum Schrad. ex Brid. & & + & \\
\hline 51. & Plagiothecium cavifolium (Brid.) Z. Iwats. & & + & \\
\hline 52. & Pseudoleskeella nervosa (Brid.) Nyholm & & + & \\
\hline 53. & Pylaisia polyantha (Hedw.) Schimp. & & + & \\
\hline 54. & Platyhypnidium riparioides (Hedw.) Dixon & & + & \\
\hline 55. & Schistidium apocarpum (Hedw.) Bruch \& Schimp. & & + & \\
\hline 56. & Scleropodium touretii (Brid.) L. F. Koch & & + & \\
\hline 57. & Thuidium tamariscinum (Hedw.) Schimp. & & + & \\
\hline 58. & Tortella fragilis (Hook. \& Wilson) Limpr. & & & + \\
\hline 59. & Tortella tortuosa (Hedw.) Limpr. & & & + \\
\hline 60. & Tortula subulata Hedw. & & & + \\
\hline
\end{tabular}

The first studied beehive yard (FVM - Faculty of Veterinary Medicine) is in the second zone of urban pollution (Grdović, 1997), but well protected by the "green ring" all around. Six soil species, 8 rock, 3 protosoil and 4 epyphyte moss species were found in this beehive yard.

The second area (Rušanj woods), has a different environmental situation as it is located outside the urban zone, so 28 species on rocks, 24 epyphytic and 16 soil species were described.

The third area (Višnjica) is situated outside the urban polluted area, but in an ecologically completely diffrent background, on dry slopes with stepic fragments. The dominant moss cover consists of soil species exclusively.

The comparison of species in the studied areas show also that diversity index (Table 2) is higher in the smallest surface of FVM yard, while in the other two larger yards is equilibrated and non significant. It gives insights that beehive yards are important in urban bryophyte diversity. Considering the relationship of bryophyte species presented in the investigated areas and environmental factors, CCA shows that the microcondition differs between the three beehive yards 
significantly (Figure 1). The relation of bryophyte presence and water is discussed hereafter. The result of PCA (Figure 2) shows that in all yards, independent of species composition, the bryophyte layer contributes to turgescency hence a longer and richer flowering period of the vascular plants above them.

Table 2. Surface of investigated area with diversity index (D1 and D2) and relationship of bryophyte cover and turgescent vascular plants presence

\begin{tabular}{|l|c|c|c|}
\hline & $\begin{array}{c}\text { Beehive 1 } \\
\text { FVM }\end{array}$ & $\begin{array}{c}\text { Beehive 2 } \\
\text { Rušanj }\end{array}$ & $\begin{array}{c}\text { Beehive 3 } \\
\text { Višnjica }\end{array}$ \\
\hline \hline Yard Surface $\mathrm{P}_{1}\left(\mathrm{~m}^{2}\right)$ & $20 \times 20$ & $30 \times 30$ & $30 \times 30$ \\
\hline Bee Pasture Surface $\mathrm{P}_{2}\left(\mathrm{~km}^{2}\right)$ & ca. 9 & ca. 9 & ca.9 \\
\hline Bryophyte species $(\mathrm{A})$ & 16 & 56 & 18 \\
\hline D1: Log $\mathrm{P}_{1} / \log \mathrm{A}$ & 2.167 & 1.686 & 1.657 \\
\hline D2: Log $\mathrm{P}_{2} / \log \mathrm{A}$ & 0.79 & 0.54 & 0.54 \\
\hline Bryophyte Layer Abundance \% & 45 & 82 & 60 \\
\hline Turgescent Vacular Plant Abundance \% & 40 & 77 & 57 \\
\hline
\end{tabular}

Considering the species composition in the studied beehive yards and its bioindication value (Winner, 1988; Grdović 1997, 2003), it can be estimated that all studied beehive yards show relatively good air quality despite of the location relative to the urban area.

In FVM beehive yards all species recorded are known to be present also in the inner urban city area of Belgrade. The beehive yard of Rušanj, the richest in

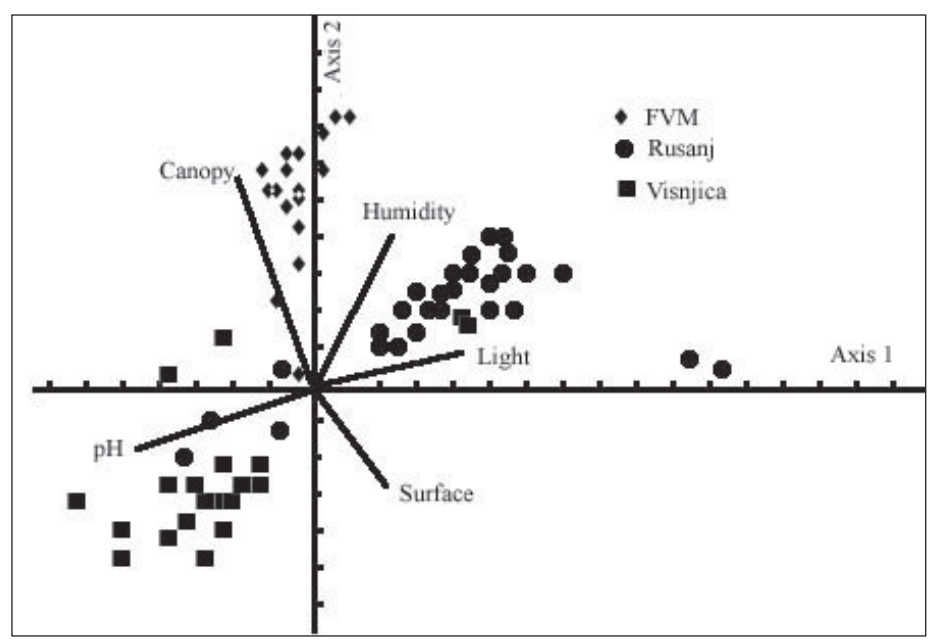

Figure 1. Canonical Correspondence Analysis Biplot of environmental preferences and bryophytes recorded in the studied beehive yards 
bryophyte species, had the best air quality. Bryophytes growing on the location support of this statement.

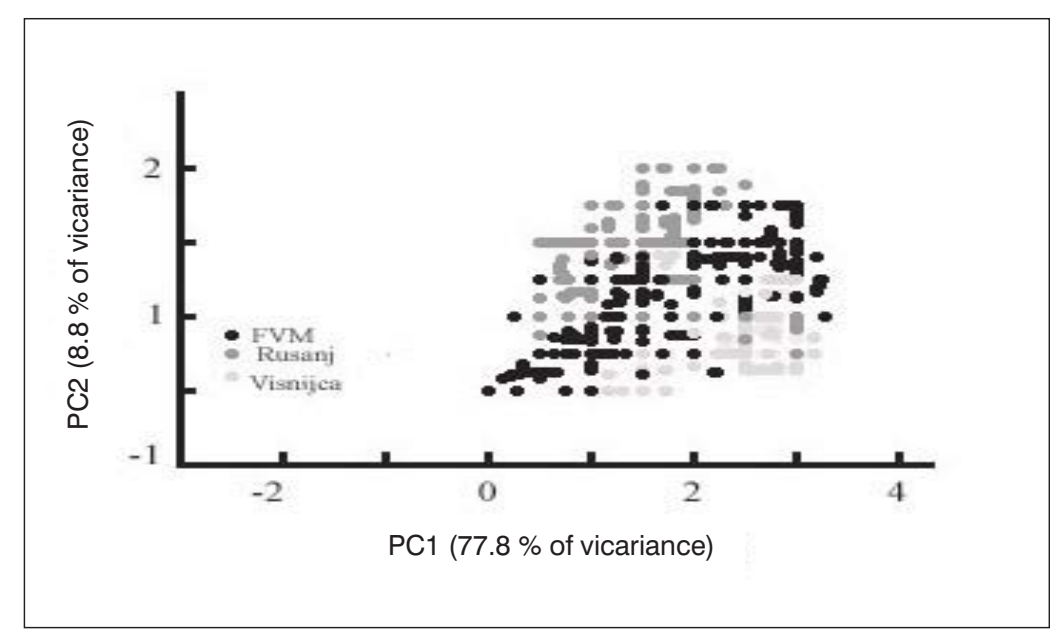

Figure 2. Principal Component Analysis of bryophyte cover in three investigated sites in correspondence to turgescent and flowering phase of vascular plant layer above

A direct relationship between domestic honey bees and bryophytes has not been confirmed. Further work is ongoing related to moss-bee relationship. The bees are caracterized as "occasionals" on bryophytes, which means that they at times can be found in bryophytes, but do not depend on these plants for their survival. Some other to bee related insects from the ordo Hymenoptera have been found and caracterized as "bryophyles" which means that they are usually found on bryophytes, but may survive elswhere and/or "bryoxenes" which means they regularly spend part of their life cycle on bryophytes (Gerson, 1982). Bryophytes are shown to have alelophatic effects to other plants indirectly influencing the organisms depending of plants (Sabovljević and Sabovljević, 2007).

However, an indirect relationship between honey bees and bryophytes is present. The meadows and prays with well developed bryophyte vegetation under the layer of vascular plants, have plants with more flowers and a longer period of flowering. It is assumed that bryophyte vegetation acts like a bio-sponge and prolonges the period of flowering and growing of vascular plants by mantaining humidity and conditions without extremes for vascular plants which grow within the bryophyte patches. Bryophytes are not competitive with flowering plants (Smith, 1982), and do not take water and mineral resorces from soils, but get them from precipitations. Rhizoids are used only for surface attachment.

According to the bees recorded in the investigated area, it can be estimated that bees do not have to fly far away from the beehive. It can be assumed that the turgescent plants and flowers provide nectar of higher quality and quantity, however further investigation in this direction is needed. 


\title{
CONCLUSION
}

Bees are facultative visitors of bryophytes. Direct relationships of bees and mosses were not found. However, indirect statistically supported relationships exist. Bryophytes when present act as a huge bio-sponge, prologe the period of turgescency and enrich flowering of vascular plants growing above them. This way they influence bees to spent more time around the beehives and do not fly long distances searching for pastures.

\author{
Address for correspodence: \\ Svetlana Grdović \\ Faculty of Veterinary Medicine \\ Bul. Oslobođenja 18 \\ 11000 Belgrade, Serbia \\ e-mail: cecag@vet.bg.ac.yu
}

\section{REFERENCES}

1. Ando H, Matsuo H, 1984, Applied Bryology, Advances in Bryology, 2, 133-225.

2. Frahm JP, 2001, Biologie der Moose, Gustav Fischer Spektrum, Heidelberg, Berlin, 357.

3. Gerson U, 1982, Bryophytes and invertebrates, In: Smith AJE, editors, Bryophyte Ecology, London: Chapman and Hall.Inc, 291-332.

4. Grdović S, 1997, Ekologija i bioindikatorski značaj mahovina užeg gradskog područja Beograda, Magistarski rad, Biološki fakultet u Beogradu.

5. Grdović S, 2003, Brioflora šireg područja Beograda - diverzitet, ekologija i bioindikatorski značaj, Doktorska disertacija, Biološki fakultet u Beogradu.

6. Hallingbäck T, 1996, Ekologisk katalog över mossor. ArtDatabanken, SLU, Uppsala,122.

7. Hill MO, Bell N, Bruggeman-Nannenga MA, Brugues M, Cano MJ, Enroth J et al. 2006, Bryological Monograph, An annotated checklist of the mosses of Europe and Macaronesia, J Bryology, 28, 198-267.

8. Jolliffe IT, 1986, Principal Components Analysis, Springer-Verlag, New York.

9. Matthey W, 1971, Ecologie des insectes aquatiques d'une tourbiere du Haut-Jura, Revue Suisse Zool, et du Museum d'Hist. Natur, Geneve, 78, 367-536.

10. Sabovljević M, Natcheva R, 2006, A check-list of the liverworts and hornworts of Southeast Europe, Phytologia balcanica, 12, 2, 169-80.

11. Sabovljević A, Sabovljević M, 2007, Bryophytes, a source of bioactive and new compounds, In: Govil JN, editors, Phytopharmacology and Therapeutic Values IV, the Series "Recent Progress in Medicinal Plants", New York, 9-25.

12. Sabovljević M, Bijelović A, Grubišić D, 2001, Bryophytes as a potential source of medicinal compounds, Lekovite Sirovine, 21, 17-29.

13. Schofield WB, 1985, Introduction to bryology, Macmillian, London, New York, 431.

14. Smith AJE, 1982, Bryophyte Ecology, Chapman and Hall, London.

15. Wagner $H H, 2004$, Direct multi-scale ordination with canonical correspondence analysis, Ecology $85,2,342-51$.

16. Winner WE, 1988, Responses of bryophytes to air pollution, In: Nash TH, Wirth V, editors, Lichenes, bryophytes and air quality, Bibl. Lichen. 30, 141-73. 


\title{
EKOLOŠKI PRILOG BRIOFLORE PČELINJAKA: POSTOJI LI ODNOS PČELA- MAHOVINA?
}

\author{
GRDOVIĆ SVETLANA i SABOVLJEVIĆ M
}

\section{SADRŽAJ}

Istraživana je flora briofita tri pčelinjaka u široj zoni Beograda. Na ispitivanim površinama proučavan je i upoređivan diverzitet briofitske flore i izučavan je odnos briofita i pčela. Vršena su posmatranja da li pčele posećuju mahovine, što je utvrđeno kao fakultativno. Ipak, indirektni odnos mahovina i pčela je pronađen i statistički značajno dokumentovan (uz pomoć principalne komponentne i kanoničke korespodentne analize, PCA i CCA). Mahovine utiču na održavanje blaže mikroklime povoljne za cvetnice koje rastu iznad njih. Na taj način im pružaju mogućnost da duže ostanu potpuno turgescentne i tokom suvljih perioda, omogućavajući na taj način duže i bujnije cvetanje, što je za pčele od izuzetnog značaja. Ovim indirektnim uticajem na pčele, mahovine im omogućavaju da ne moraju da lete na duže distance u potrazi za ispašom. 